\title{
The Metabolic Route of Degradation of the Vat Dye Sulfur Blue Brn and Corresponding Ecotoxic Effect
}

\author{
Swapnil R Jadhav, Rohit M Dake, Aditi S Kamat, Archana B Jagtap and Jai S Ghosh* \\ Department of Biotechnology, Smt KW College, India
}

Submission: June 12, 2018; Published: July 05, 2018

*Corresponding author: Jai S Ghosh, Department of Biotechnology, Smt KW College, India, Tel: +919850515620; Email: ghoshjai@gmail.com

\begin{abstract}
The dyes are a part of everybody's life. These are mostly used to color textile, food, paper and as paint. Previously dyes from natural sources were mostly commonly used but with the advances of synthetic chemical sciences, the synthetic dye is a growing industry along with its widespread application. This has resulted in generation of large quantity of colored effluent having different ecotoxic effects. Of all the dyes the insoluble vat dyes are highly toxic as they tend to accumulate in the environment thus causing imbalance in the biodiversity. This investigation deals with one such vat dye sulphur blue BRN which is used in place of indigo to color jeans. The microorganism Pseudomonas has been found to carry out the degradation thus detoxifying it as exemplified in the mitotic index results of meristematic cells of Allium cepa. The hypothetical metabolic route for degradation is derived from Infrared spectroscopic data as well as GCMS data.
\end{abstract}

Keywords: Vat Dyes; Pseudomonas; Ecotoxicityl; Sulfur Blue Brn; Biodiversity

\section{Introduction}

Color is a part of every living organism's life [1]. It is therefore, a very important part of human life too [2]. Before the industrial revolution natural dyes were widely used for coloring food, clothing and shelter [3]. These were mainly obtained from different plant materials. As time progressed alternative sources of dyes were being searched and with advances in synthetic chemical sciences, artificial dyes were discovered [4]. This was very significant development of the industrial revolution in the world, especially in the manufacture of vibrant colored fabrics for clothing thereby increasing their market value [5]. Such synthetic chemical dyes had considerable reduced cost [5] and people started to use these indiscriminately, resulting in different toxic effects in the environment as many of these were either recalcitrants or slow biodegradable compounds [6].

Textile industry is therefore, considered today to be the largest users of synthetic dyes [7]. In fact only 5 to 10 percent of the dye is fixed on the fabrics and the remaining enters the effluent from these industries [8]. Similarly the next big user of dyes are the food processing industries, packaging material industry followed by the paper and pulp industry, the paint industry etc. If these colored effluents are not treated before being discharged into the environment, then these may show anything from genotoxic effects on living organisms to interfering with penetration of sunlight into fresh water bodies thus changing the biodiversity right from the planktonic level
[8]. Such ecotoxic effects, gave rise to the search for methods for detoxifying the effects of such synthetic dyes. These studies primarily aimed at decolorizing the dyes that is remediation of the chromophore groups in particular. There are chemical methods which are developed in this direction of research [9]. However, these have been found to give rise to secondary pollutants. The remediation of these secondary pollutants added to the cost of effluent treatment which many of the industries were reluctant to invest. Finally as of date, there is considerable interest in biological methods of remediation, which are broadly classified as either phytoremediation (using plant material) or microbial remediation (where the metabolism of certain microbes is exploited for the purpose) [10].

The second important aspect of such bioremediation is to classify these dyes in various groups [11]. The two main groups of the dyes that are usually the major pollutants are the azo dyes and the vat dyes. The bioremediation of azo dyes have been and are being extensively studied because these dyes are soluble in water at neutral or near neutral $\mathrm{pH}$ values [11]. On the other hand there are very few reports of bioremediation of vat dyes as these are usually insoluble in water or soluble at alkaline $\mathrm{pH}$ values. At neutral or near neutral $\mathrm{pH}$ values they usually remain as sediment in the environment and tend to accumulate in the environment [11]. In this study, bioremediation of one such vat dye, sulfur blue BRN has been studied (Figure 1). 


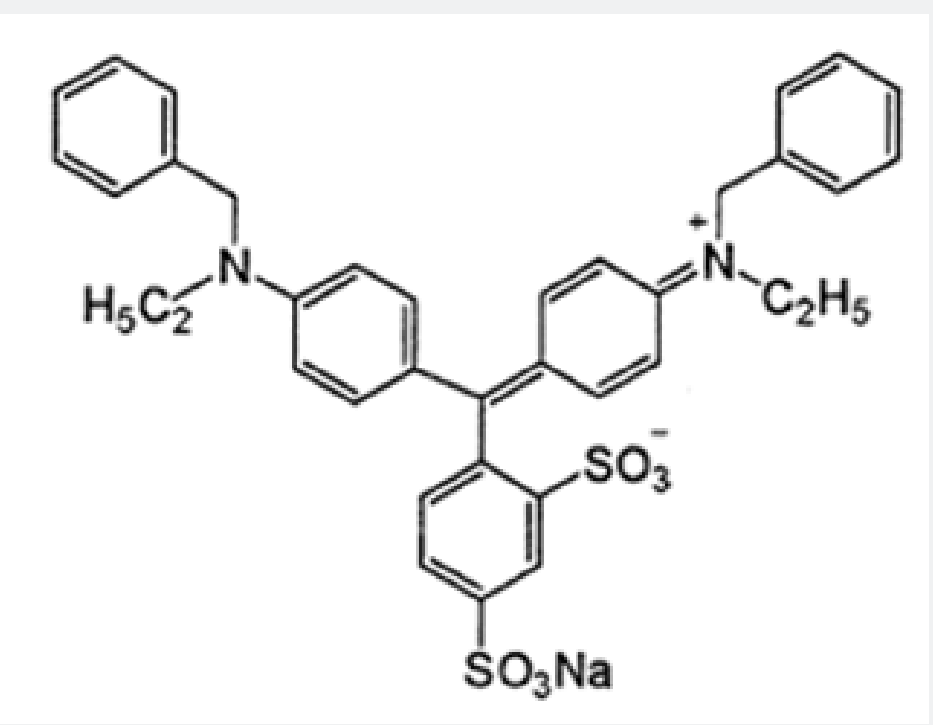

Figure 1: The molecular structure of sulfur blue BRN.

This dye is usually used as a alternative to indigo which is used to color jeans. Indigo is extracted from the plant Indigofera tinctoria [12]. Again the prohibitive cost of this natural dye has made alternative synthetic compounds more affordable to the industry as well as to the consumers.

\section{Material and Methods}

\section{The Microorganism Used}

Here the specific identification of the microorganism was not of primary interest. Generic level identification was more than sufficient. The medium used had the following composition: Tryptone $1 \%$; $\mathrm{NaCl} 0.5 \%$; Yeast extract $0.01 \%$ at pH 8.5 . The dye was added at different concentration like $2 \mathrm{ppm}, 4 \mathrm{ppm}, 6 \mathrm{ppm}$ and $8 \mathrm{ppm}$ separately. At $10 \mathrm{ppm}$ and more it was found to be inhibitory. The untreated effluent was collected from a local textile industry using the dye. The effluent was added at $1 \%$ $(\mathrm{v} / \mathrm{v})$ level and the flasks were incubated at $28 \mathrm{oC}$ to $30 \mathrm{oC}$ for 5 days on a rotary shaker at $150 \mathrm{rpm}$. After the incubation the growth was placed on solid medium of the same composition containing 4ppm of the dye. The isolated colonies were identified using Bergey's manual of determinative bacteriology [13] and maintained on the same solid medium by serial transfer.

\section{Dye Degradation Studies}

The studies were carried out in minimal liquid medium (peptone $1 \% ; \mathrm{NaCl} 0.5 \%$, Urea $0.5 \%$ and glucose $0.5 \%$ at $\mathrm{pH} 8.5$ ) and the dye was added at $4 \mathrm{ppm}$ level unless otherwise stated. The inoculum was added at $1 \%(\mathrm{v} / \mathrm{v})$ of a suspension of absorbance 0.4 at $550 \mathrm{~nm}$. Incubation was carried out for $24 \mathrm{hrs}$ to $48 \mathrm{hrs}$ on a rotary shaker of speed $150 \mathrm{rpm}$. Visual decolourization was first observed followed by detailed analysis.

Detailed analysis of the degraded product. Degradation was confirmed by Infra Red Spectroscopic studies. This was followed by GCMS studies after extraction with methanol. The extracts of cell-free medium were analyzed by GCMS (Trace GC ultra Polaris Q Technologies), equipped with a DB-530-m fused silica capillary column $(0.25 \mathrm{~mm}$, i.d. and $0.25 \mu \mathrm{m}$ film thickness $)$, and attached to a mass spectrophotometer. Samples were injected in splitless mode at $50{ }^{\circ} \mathrm{C}$. The column was maintained at $50{ }^{\circ} \mathrm{C}$ for an initial $1.5 \mathrm{~min}$, followed by heating at $140{ }^{\circ} \mathrm{C}$, then to $210^{\circ} \mathrm{C}$ and finally to $250^{\circ} \mathrm{C}$. Helium was used as carrier gas.

\section{Ecotoxic pattern of Sulfue Blue BRN and its degraded product}

This experiment was carried out using the mitotic index results of the meristematic cells of Allium cepa root tip [14].

\section{Results and Discussion}

Since this investigation was limited to find out the mechanism of degradation of the vat dye sulfur blue BRN, no attempts were made to optimize different parameters for maximum degradation. The organism isolated belonged to the genus Pseudomonas as seen from the tests as per Bergeys manual $9^{\text {th }}$ edition [13], which did not show any pigmentation. Also no efforts were made to carry out the species level identification as the strain showed high degree of similarity with the non pigmenting identified strain available in the laboratory (Pseudomonas aeruginosa NCIM 2112).

The results of Infra red spectroscopic studies of the original dye molecule and those of the degraded product are shown in Figure 2. It can be seen from the figure that many of the functional in the original dye molecules has disappeared and certain new functional groups have reappeared. The best example is that a large peak is seen around $3333 \mathrm{~cm} 1$ indicating the formation of amine group. This is a stretched peak (Figures $2 \mathrm{a} \& 2 \mathrm{~b}$ ). 


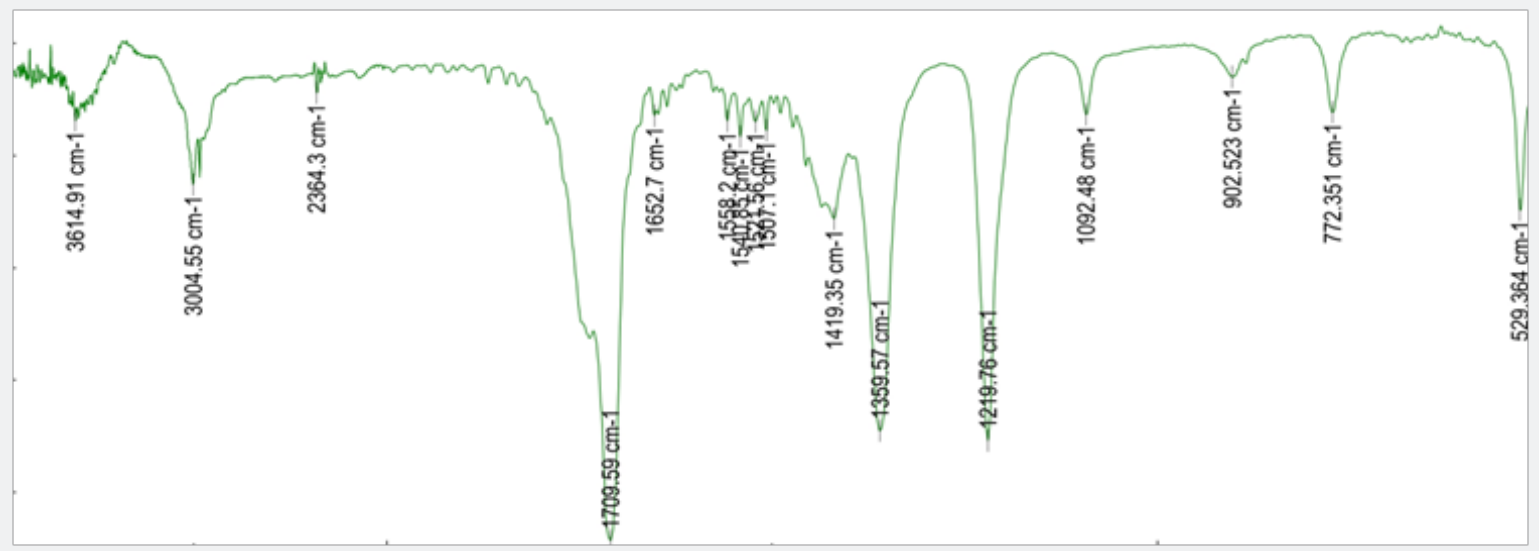

A

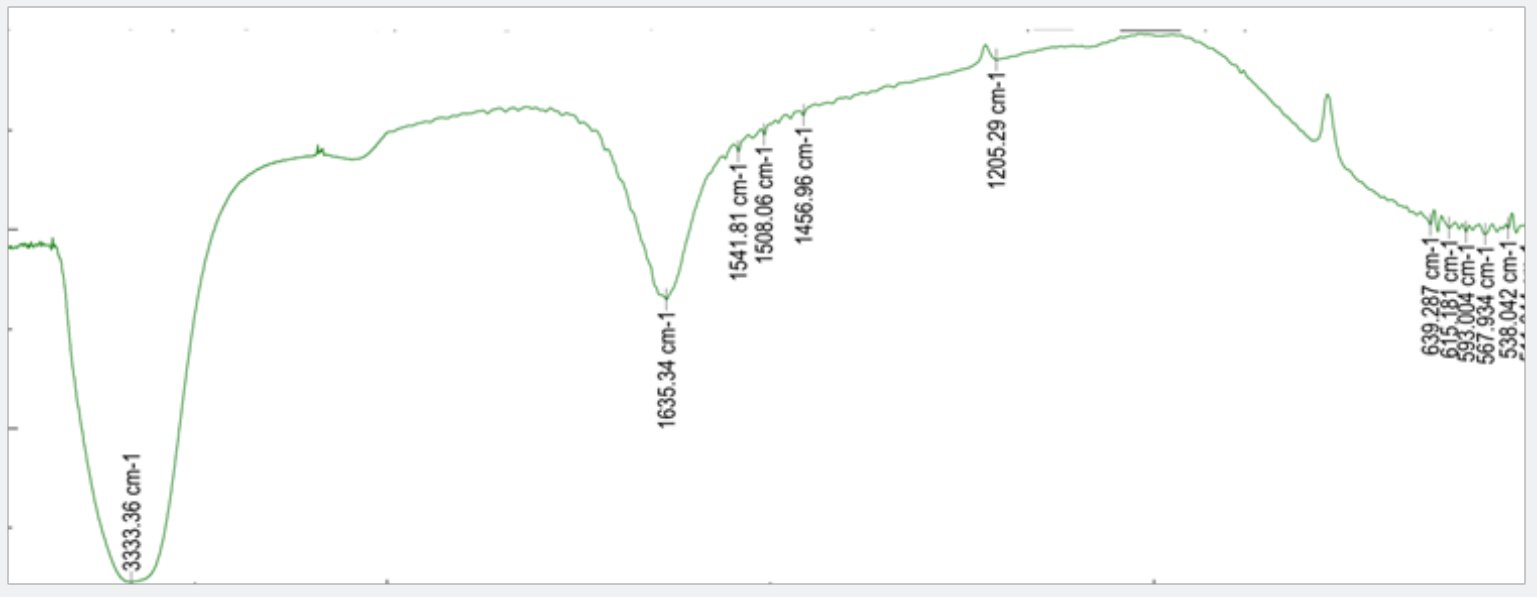

B

Figure 2: The original dye molecule is as shown in A and that of the degraded products are shown in $\mathrm{B}$.

Likewise when sees the GCMS peaks in Figure 3 then one gets to see 2 major peaks of $\mathrm{m} / \mathrm{z}$ at 147 and 207 as shown below: This concurs with the IR spectroscopic data. Finally the ecotoxic effect as observed showed the undegraded dye in the uninoculated medium was having a mitotic index of $88 \%$ (such high mitotic index could be due to the insoluble nature of the dye at or near neutral $\mathrm{pH}$ ) as compared with that of distilled water $(82 \%)$. However, the degraded product of the dye was showing a mitotic index of $92+\%$ (Figure 3).

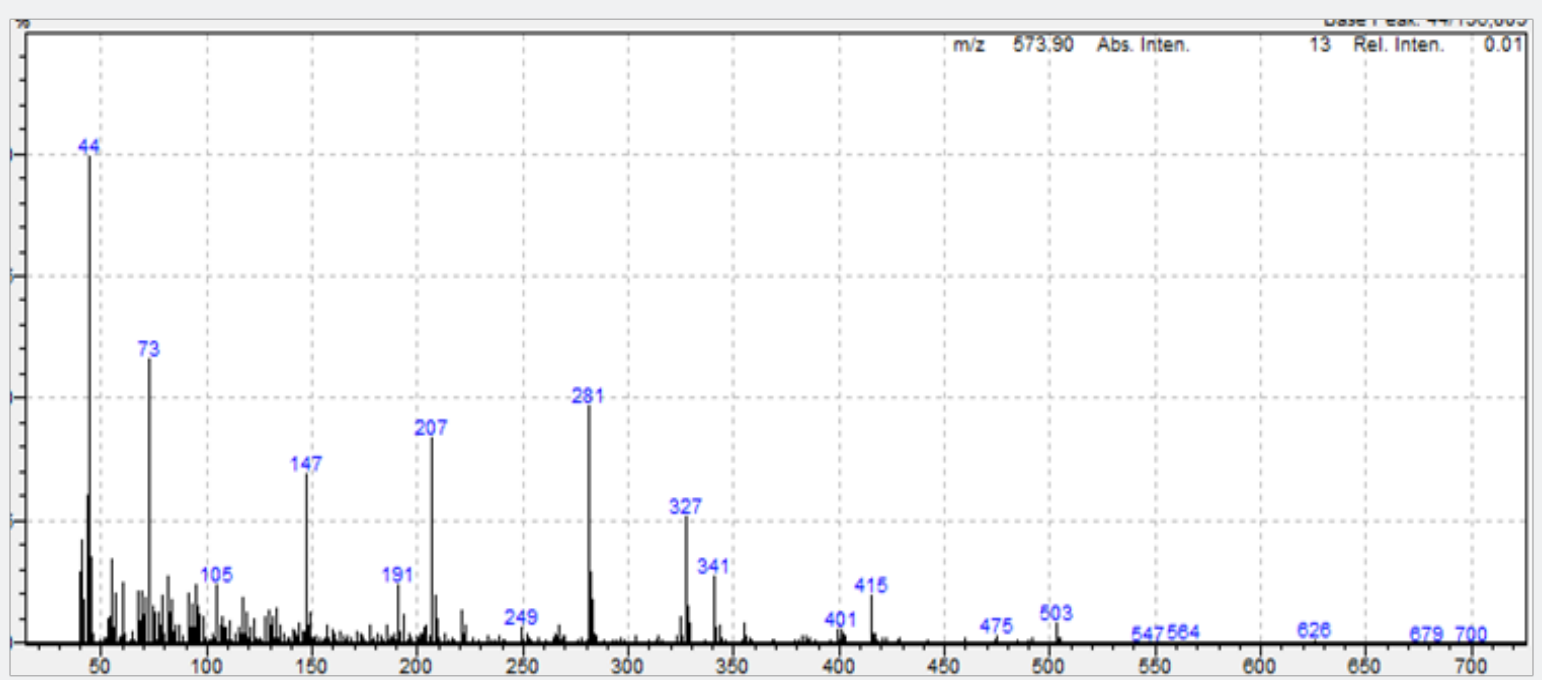

Figure 3: The GCMS results of the original dye molecule and its degraded products. 


\section{Conclusion}

With these three observations it was hypothesized that the degradative route of the vat dye Sulfur Blue BRN could be the results of ecotoxity results indicate that the degraded products were more eco freindly rather than ecotoxic (Figure 4).

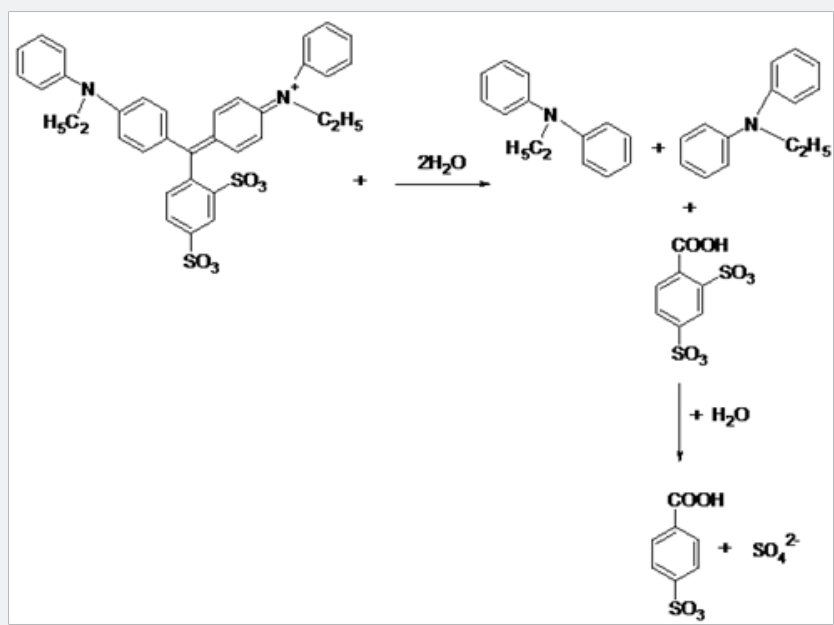

Figure 4: The probable hypothetical metabolic route of degradtion of the vat dye sulfur blue BRN.

\section{Acknowledgement}

The authors are grateful to the authorities of Smt. KW College, Sangli, India, for having extended the laboratory facilities for successful completion of this work.

\section{References}

1. http://blog.teamtreehouse.com/how-colour-communicates-meaning

2. https://psychologenie.com/the-power-of-colors-their-meanings

3. http://www.allnaturaldyeing.com/natural-dye-colors/

4. Zollinger H (2003) Color Chemistry. Synthesis, Properties and Applications of Organic Dyes and Pigments. Weinheim: Wiley-VCH.

5. http://www.nptel.ac.in/courses/116104046/6.pdf

6. Ece Ümmü Deveci, Nadir Dizge, Hüseyin Cengiz Yatmaz, Berrin Tansel (2016) Degradation of Recalcitrant Textile Dyes by Coupling Fungal and Photocatalytic Membrane Reactors, Clean, soil air water 44: 13451351.

7. Dos Santos AB, Cervantes FJ, van Lier JB (2007) Review paper on current technologies for decolourisation of textile wastewaters:

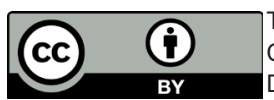

This work is licensed under Creative

Commons Attribution 4.0 License

DOI: 10.19080/IJESNR.2018.13.555853
Perspectives for anaerobic biotechnology. Bio-resource Technology 98(12): 2369-2385.

8. Rita K (2012) Textile dyeing industry an environmental hazard. Natural Science 4(1): 1-5.

9. Kandisa RV, Narayana Saibaba KV, Shaikh K B, Gopinath R (2016) Dye Removal by Adsorption: A Review. Journal of bioremediation and biodegradation 7(6): 1-4.

10. Kandelbauer A, Guebitz GM (2005) Bioremediation for the Decolorization of Textile Dyes A Review. In Lichtfouse E, Schwarzbauer J Robert D (Eds.), Environmental Chemistry. Springer, Berlin, Heidelberg, USA.

11. Booth G (2000) Dyes, General Survey. Wiley VCH.

12. Splitstoser JC, Dillehay TD, Wouters J, Claro A (2016) Early preHispanic use of indigo blue in Peru. Science Advances 2(9): 1501623.

13. Bergey D, Holt JG (2000) Bergey's manual of Determinative Bacteriology ( $9^{\text {th }}$ edn.), Lippincott Williams \& Wilkins, Philadelphia US.

14. Nefic H, Musanovic J, Metovic A, Kurteshi K (2013) Chromosomal and Nuclear Alterations in Root Tip Cells of Allium Cepa L. Induced by Alprazolam, Medical Archives 67(6): 388-392.

\section{Your next submission with Juniper Publishers will reach you the below assets}

- Quality Editorial service

- Swift Peer Review

- Reprints availability

- E-prints Service

- Manuscript Podcast for convenient understanding

- Global attainment for your research

- Manuscript accessibility in different formats

( Pdf, E-pub, Full Text, Audio)

- Unceasing customer service

Track the below URL for one-step submission https://juniperpublishers.com/online-submission.php 